\title{
Design and development of SEPIC DC-DC boost converter for photovoltaic application
}

Ibrahim Alhamrouni ${ }^{1}$, M. K. Rahmat ${ }^{2}$, F. A. Ismail ${ }^{3}$, Mohamed Salem ${ }^{4}$, Awang Jusoh ${ }^{5}$, T. Sutikno ${ }^{6}$

$1,2,{ }^{3}$ Electrical Engineering Section, University Kuala Lumpur (UniKL BMI), Malaysia

${ }^{4}$ School of Electrical and Electronic Engineering, Universiti Sains Malaysia, Malaysia

${ }^{5}$ Faculty of Electrical Engineering, Universiti Teknologi Malaysia, Malaysia

${ }^{6}$ Department of Electrical Engineering, Universitas Ahmad Dahlan, Indonesia

\begin{tabular}{l}
\hline Article Info \\
\hline Article history: \\
Received Sep 17, 2018 \\
Revised Nov 8, 2018 \\
Accepted Dec 3, 2018 \\
\hline
\end{tabular}

Keywords:

DC-DC converter

High voltage gain

Low ripple

Renewable energy

SEPIC DC-DC converter

\begin{abstract}
This study highlights a new construction of SEPIC DC-DC converter. The proposed converter aims for some features such as high voltage gain, continuous input current and reduce stress on the power switch. In addition, the circuit construction ensurs the simplicity in design along with signicant cost saving, since its components are readily available and smaller in size compared to the off-shelf components. This type of converter can adjust the DC voltage to maintain its output voltage to be constant. Typically, SEPIC operated in equipment that uses battery and also in wide range input voltage DC power supply. The converter is designed for renewable energy application where it is able to regulate the output voltage of the Photovoltaic (PV). The converter has been analysed based on different switching frequencies and duty cycle. Thus the outcome of the proposed converter can be achieved by using $\mathrm{D}=0.45$ and $\mathrm{fs}=30 \mathrm{kHz}$. The proposed converter is supplied by $26 \mathrm{~V}$ as an input voltage and produces $300 \mathrm{~V}$ output and gives $94 \%$ of efficiency.
\end{abstract}

Copyright (C) 2019 Institute of Advanced Engineering and Science. All rights reserved.

\section{Corresponding Author:}

Ibrahim Alhamrouni,

Electrical Engineering Section,

University Kuala Lumpur British Malaysian Institute (UniKL BMI),

Gombak 53100, Malaysia.

Email: ibrahim.mohamed@unikl.edu.my

\section{INTRODUCTION}

Current global situation is experiencing a rapid and fast technological growth and physical development. This situation has led to an increase demand for energy because energy plays a central role in overall development process. As of current, fossil fuels are the primary source for energy. However, it becomes a challenge to solely rely on fossil fuels due to its source is experiencing a depletion. In addition to limited resources, fossil fuels which are non-renewable energy source give various risks and hazards to human and environment such as global warming [1], [2]. Besides, the unstable global fuel price also provides challenge for fossil fuel to remain as primary energy source [3]. Given these problems, it thus drives the exploration of other alternatives for power generation with higher efficient ways for energy harvesting from different sources. Renewable energies such as solar, wind and hydropower have been considered since these types of energies are more clean, reliable, certain, illimitable and irrepressible with practically zero emission [1]. In fact, these types of energy application have become a focus in academic and industry research for decades [4]. Renewable energy business is amplifying fast and expected to be a need for power generation of today's world [5]. However, energy storage devices- called an accumulator or battery are needed due to the interrupted feature of renewable energy sources. This is due to the need to stabilize the electricity generation and its consumption [4]. Energy storage includes the process of energy conversion from the forms that are 
difficult to store to another form that is easier to be stored. Grid utility might sometimes be unavailable; therefore, storage device is necessary. Besides that, storage device is also important when excess energy is generated from the renewable energy sources [6]. However, the system depends on the traditional converters which generates high cost due to numerous components and make the complexity of the control be increased [4].

Solar photovoltaic (PV) has proven that it can be the largest renewable energy sources to reaching the European target of $20 \%$ by 2020 . The improvement of technology and economies of scale have triggered cost minimization, and this will continue for the coming years as PV business becomes the other energy sources major competitive. This system can reduce environmental issues such as greenhouse effect, climate change, global warming and pollution [5]. Energy generation by PV cells is DC which requires conversion to $\mathrm{AC}$ to be supplied to the grid/load. Besides, due to weather changes such as sunlight intensity and cell temperature PV becomes a nonlinear power source that affects its system performance. The other factors that affect the output power from PV module are position of the sun during the daytime. Irradiation and PV cell temperature are also among the factors that affect PV performance [7]. Therefore, this renewable energy system needs to have a DC-DC converter and DC-AC converter to make the energy storage to be possible. DC-DC conversion method consists of a voltage divider, potentiometer and switching as the simplest construction. However, this simple method results in poor efficiency [6] and needs to be improved in order to meet the industrial and commercial demands. There are many topologies that have been suggested to implement the converter. Some of the topologies are cascade H-bridge, coupled inductor and multilevel input. However, there are still some limitations to produce the output voltage with high efficiency and without having synchronization problems. Photovoltaic (PV) and wind energy are among the sources of renewable energy. These types of renewable energy are sustainable, reliable and abundance in market which make them to be more advantageous than the fossil fuel that currently is depleting. For this, the world is currently driving towards green energy type that makes these types of energy and their application to be crucial [8], [9] and [10]. The output voltage of PV panels needs to be boosted and step-up due to its low output voltage. This is to enable the voltage to match with the grid integration. However, this causes the application of renewable energy to be rather difficult. Therefore, consideration for power electronic converter had become the best solution for this problem [8]-[10]. The connection between the power generation and the grid consists of DC-DC converter and DC-AC inverter. The DC-DC converter should be able to obtain a high voltage conversion which the increased voltage will be connected to the inverter and finally to the grid. The input current characteristic also has become one of the challenges for the DC-DC converter as PV panels required a maximum power point tracking (MPPT). The MPPT is only performed if the input current of the converter is a continuous current. As [8] mentioned, the dynamic performance of the system will be increased with the continuous input current of the DC-DC converter. The crucial elements of DC-DC converter that are to be used for renewable energy application as said by [9], [10] are continuous input current and high voltage gain. In addition, the conventional boost converters also can also be used as well in this application as a single-switch single-stage structure [8]. However, conventional converter has low voltage conversion gain which is not enough for the application of renewable energy [11]-[16]. This makes the conventional converter to be unsuitable for this application. In high duty ratios, the power switch will make the converter performance to be affected and deteriorated severely even though the conventional converter can reach the high voltage gain.

This work aims to design and develop a DC-DC converter to regulate and control the output voltage of the renewable energy sources focusing on PV. This paper explains the importance of new SEPIC-based converter topology instead of other type of DC-DC converter topologies. The optimization of DC-DC and control is highlighted since the emphasis is on the converter output control by using MOSFET as the power switch. A new high step-up DC-DC converter by using the SEPIC-based concept is presented which brings the advantages of the previous SEPIC converter. This method addresses the advantages of this new topology which are having continuous input current and high voltage conversion gain. Besides that, this topology is also able to reduce voltage stress on the power switch.

\section{CIRCUIT CONFIGRATON AND OPERATION PROCEDURE}

The curcuit configuration of the proposed SEPIC converter is shown in Figure 1. The conveter consists of DC voltage Source, five capacitors, three inductors, a MOSFET switch, and four diodes and coupled inductor. The voltage across the main switchis clamped by capacitor $\mathrm{C} 1$ and diode $\mathrm{D} 1$. This reduces the conduction loss. While, capacitors C3 and C4 are charged by both sides of the coupled inductor. The utilized componants values are tabled in Table 1.

Figure 2 shows the principle of operation of the converter for each mode. Mode I started as soon as the switch is on and mode $\mathrm{V}$ ended when the switch is on again for the next switching period. The circuit

Design and development of SEPIC DC_DC boost converter for photovoltaic... (Ibrahim Alhamrouni) 
construction of the proposed project is shown in Figure 2. The values of all capacitors are assumed large to make the analysis simple. This is to ignore the voltage ripples in the capacitor. Therefore, voltage gain in steady state can be obtained. Besides, the semiconductors in this circuit are also assumed ideal. The mode operations are divided into five modes. Each mode has different operation based on the current flow path.

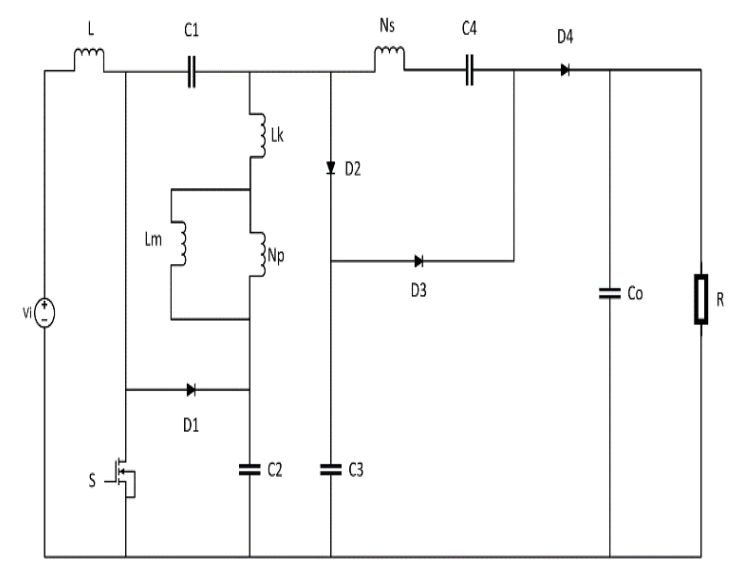

Figure 1. The circuit configtation of the proposed converter
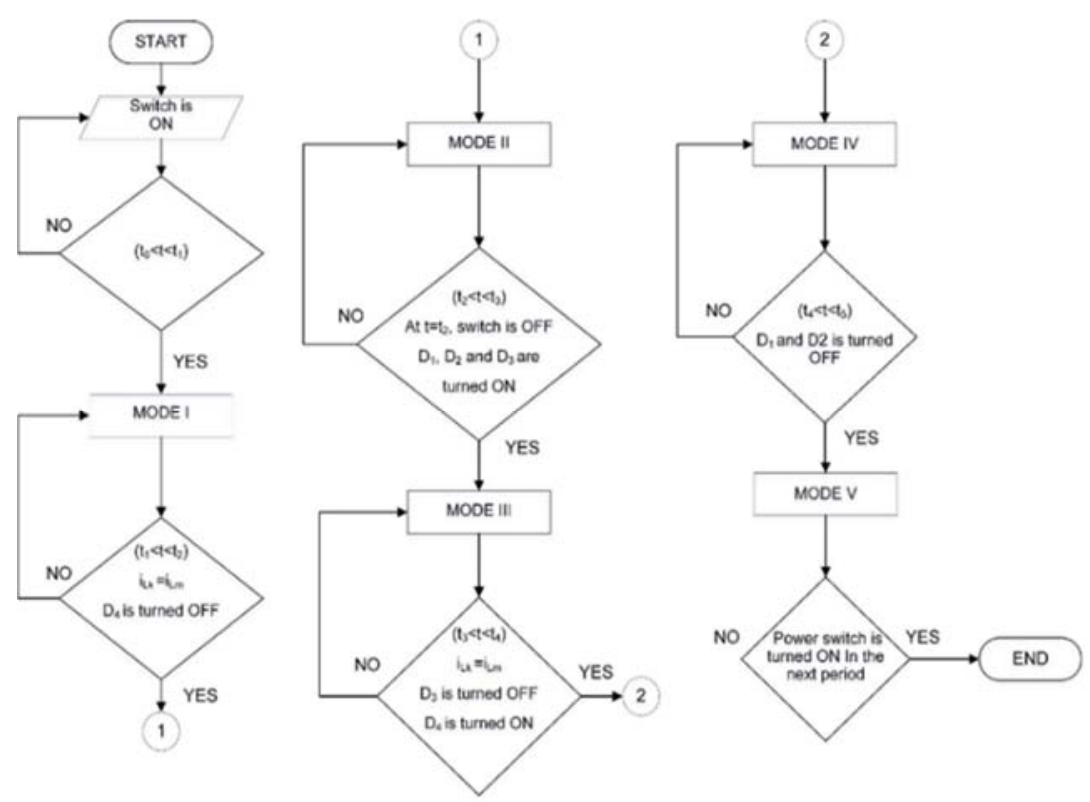

Figure 2. Flowchart of the proposed converter operation

Table 1. Parameter of each component for the proposed converter

\begin{tabular}{cc}
\hline Specifications & Values \\
\hline Input voltage & $26 \mathrm{~V}$ \\
Capacitors & $\mathrm{C}_{1}, \mathrm{C}_{2}, \mathrm{C}_{3}, \mathrm{C}_{4}=47 \mathrm{uF}$ \\
& $\mathrm{C}_{0}=180 \mathrm{uF}$ \\
Inductors & $\mathrm{L}=320 \mathrm{uH}$ \\
& $\mathrm{Lm}=100 \mathrm{uH}$ \\
$\mathrm{Lk}=1 \mathrm{uH}$ \\
$\mathrm{n}=2$ \\
Switching frequency & $30 \mathrm{kHz}$ \\
Power switch & MOSFET \\
\hline
\end{tabular}

Int J Pow Elec \& Dri Syst, Vol. 10, No. 1, March 2019: $406-413$ 
At the coupled inductor, the current of the secondary side cannot be change simultaneously due to the inductor currents. Therefore, its current equation can be written as:

$$
i_{L S}=\frac{i_{L m}-i_{L k}}{n}
$$

$i_{L s}$ is the secondary winding current, $i_{L m}$ is the primary winding current, $i_{L k}$ is the leakage inductive current.

$$
n=\frac{N_{S}}{N_{p}}
$$

Where $\mathrm{N}_{\mathrm{p}}$ is the primary winding, and $\mathrm{N}_{\mathrm{s}}$ is thesecondary winding

The minimum value of inductor, $\mathrm{L}$ and magnetizing inductor $\mathrm{L}_{\mathrm{m}}$ can be calculated as below:

$$
\begin{aligned}
L & \geq \frac{D R_{L}}{2 M^{2} f_{s}} \mathrm{~L} \geq 29.7 \mathrm{uH} \\
L_{m} & \geq \frac{L D R_{L}}{2 L M(1+M) f_{S}-D R_{L}} \\
L_{m} & \geq 26.97 u H
\end{aligned}
$$

However, since these are the minimum value of $\mathrm{L}$ and $\mathrm{L}_{\mathrm{m}}$ for the proposed converter to operate under CCM condition, this factor may affect the converter to work near the DCM condition. Therefore, in order to avoid this issue, the design of converter should consider the $20 \%$ of allowable ripple current that passes through the inductors. Therefore, the integral formula as below is used to consider the value of $\mathrm{L}$ and $\mathrm{L}_{\mathrm{m}}$ that can fully operate under CCM condition.

$$
\begin{gathered}
\Delta i_{L}=\frac{D V_{i}}{L f_{S}} \\
\Delta i_{L m}=\frac{D V_{i}}{L m f_{S}}
\end{gathered}
$$

Based on (3), (4), (5) and (6) the value of $\mathrm{L}$ and $\mathrm{Lm}$ is selected to be $320 \mathrm{uH}$ and $100 \mathrm{uH}$.

\section{RESULTS AND DISCUSSION}

In order to analyze the circuit performance, the circuit is constructed in Matlab Simulink. From the simulation, output voltage, output current, voltage across capacitors and current flows through inductors can clearly be seen and explained. In order to obtain the steady state operation of the voltage gain, the capacitors value of all capacitors must be large enough to neglect the voltage ripples, the semiconductors that have been selected are all ideal. In this section, the discussion of the results will be divided into five sub-sections as the proposed converter has been implemented and tested under various operation conditions which are: varried the duty ratio $\mathrm{D}$, varried switching frequency fs, comparison of circuit operation with different type of power switch, output of the proposed converter and voltage gain.

\subsection{Proposed converter operation under duty cycle, $d$ variation}

In this section, the proposed converter is operated under the same frequency, fs which is $30 \mathrm{kHz}$ and the same input voltage, $\mathrm{Vi}=26 \mathrm{~V}$ but with varies duty cycle, $\mathrm{D}(\mathrm{D} \geq 0.4)$. The power switch that has been used is MOSFET. 


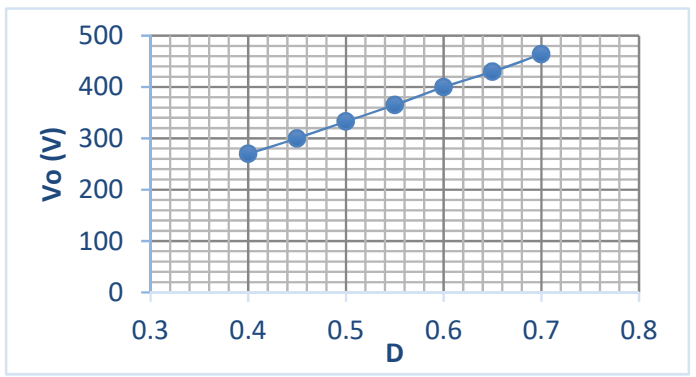

Figure 3. The value of output voltage Vo by using different duty cycle

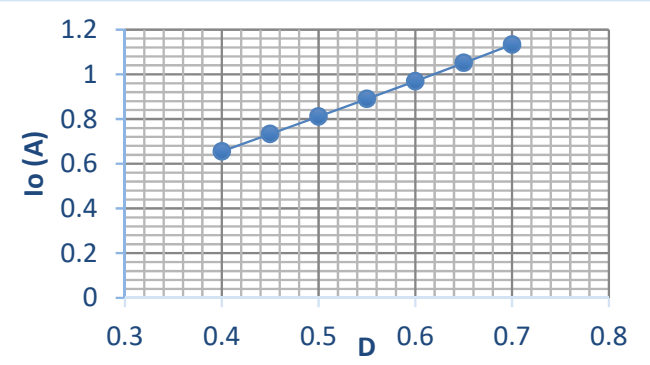

Figure 4. The value of output current Io by using different duty cycle

From Figure 3 and Figure 4, it is clearly show that when the duty cycle, D is increases, the output voltage, Vo is also increasing. This happens because of the voltage gain, M formula as mentioned below. When the duty cycle, D is increased, the voltage gain, $\mathrm{M}$ is increased, so does the output voltage.

$$
\mathrm{V}_{\mathrm{O}}=\mathrm{MV}_{\mathrm{i}}
$$

However, the value of output current, $\mathrm{I}_{\mathrm{O}}$ cannot be assumed simply because of the increase of the output voltage, $\mathrm{V}_{\mathrm{O}}$. The output current can be calculated by using below equation:

$$
I_{i}=M I_{O}
$$

\subsection{Proposed converter operation under switching frequency, fs variation}

In this section, the circuit is operated under the same duty cycle, D and the same input voltage, $\mathrm{Vi}=26 \mathrm{~V}$ but with different switching frequency, $\mathrm{fs}_{\mathrm{s}}\left(\mathrm{f}_{\mathrm{S}} \geq 10 \mathrm{kHz}\right)$. The power switch that has been used is MOSFET.

From Figure 5, it shows that when the switching frequency, $\mathrm{f}_{\mathrm{s}}$ is increasing, the output voltage, $\mathrm{V}_{\mathrm{O}}$ decreases as well. In this case, the range of switching frequency $f_{s}$ is determined by the value of the output voltage, $\mathrm{V}_{\mathrm{O}}$. Higher switching frequency will reduce the size of components and also reduce the output ripple. Switching frequency is the rate of the switch to switch on and off during the modulation process from the pulse generator. From Figure 6, it shows that when the switching frequency, fs is increases, the input current $\mathrm{I}_{\mathrm{i}}$ is decreases. This happens due to high switching frequency that leads to higher switching losses.

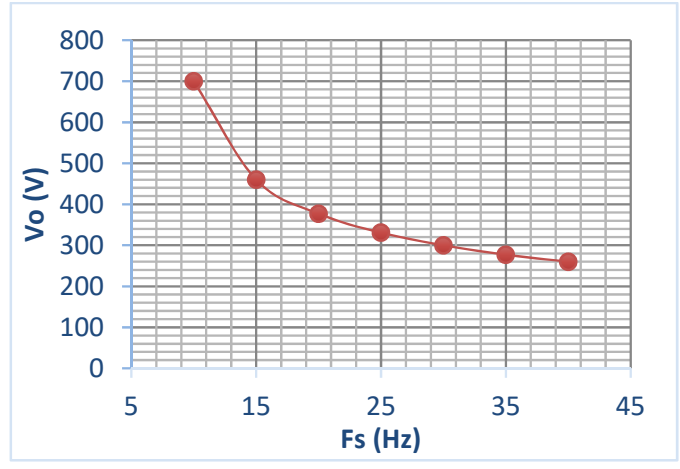

Figure 5. The value of output voltage Vo by using different switching frequency

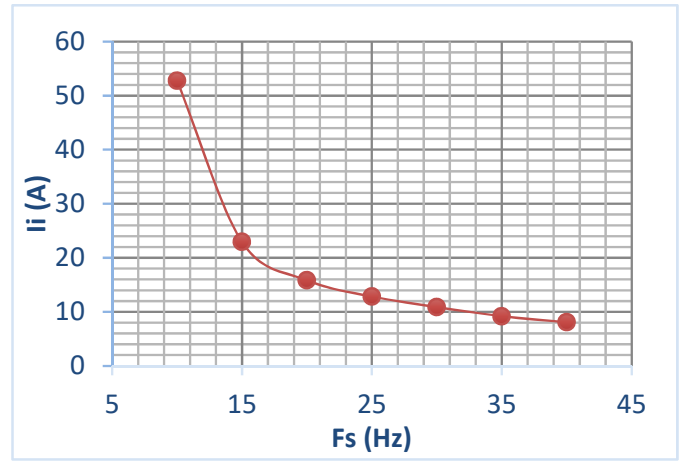

Figure 6 . The value of input current, $I_{i}$ by using different switching frequency

\subsubsection{Comparison of circuit operation with different type of power switch}

In this section, two power switches which are MOSFET and IGBT are being compared. The circuit is operated under the same duty cycle, D and the same switching frequency, fs which is $30 \mathrm{kHz}$. The power 
switches that have been compared are between MOSFET and IGBT. From both Figures 7 and 8 , it is clearly showing that MOSFET has a higher ability to have high voltage gain when compared to IGBT.

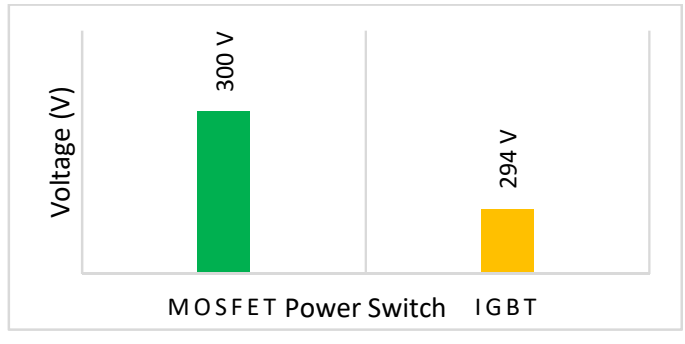

Figure 7. Output voltage by using different type of switch

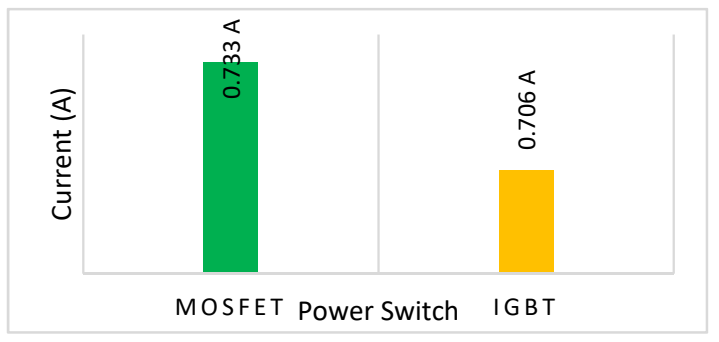

Figure 8. Output current by using different type of switch

Therefore, for this proposed converter, MOSFET has been chosen to be the most suitable the power switch for the converter operation. In addition, the converter operation has lower the voltage stress and current stress on the power switch. Hence, the power switch will be able to operate away from its saturation region. The voltage stress on the switch, Vs can be calculated as the formula (9):

$$
V_{S}=\frac{M}{n+2} V_{i}
$$

Meanwhile the current loss on switch, $\mathrm{I}_{\mathrm{s}}$ can be calculated as the formula (10):

$$
\mathrm{I}_{\mathrm{S}}=\mathrm{MI}_{\mathrm{O}}+\left[\frac{2(\mathrm{n}+1)}{\mathrm{D}}\right] \mathrm{I}_{\mathrm{O}}
$$

\subsubsection{Output of the proposed converter}

After analyzing the effect of duty cycle, D and switching frequency, fs to the proposed converter operation, $\mathrm{D}=0.45$ and $\mathrm{fs}=30 \mathrm{kHz}$ have been chosen to be the optimal values for the proposed converter to perform its operation. Based on the comparison between MOSFET and IGBT, MOSFET is selected to operate in this converter. The MOSFET is getting the signal from the pulse generator. The pulse generated is an open loop pulse which does not include any controller. The input voltage is kept constant which is $\mathrm{Vi}=26 \mathrm{~V}$. In this proposed converter, square wave pulse is used to trigger and give signal to the gate of MOSFET.

Figure 10 displays the input current of the proposed converter. The input current $\mathrm{I}_{\mathrm{i}}$ is measured to be the same as inductive current $\mathrm{i}_{\mathrm{L}}, \mathrm{I}_{\mathrm{i}}=\mathrm{i}_{\mathrm{L}}$. This is because the function of inductor $\mathrm{L}$ itself is to provide a smooth input current of the proposed converter. From Figure 9, it shows the inductive current $i_{L}$ is approximately 9A and its ripple is low. Hence, this makes the ripple of the input current is also to be low. The uses of passive clamp circuit in this converter operation which is the $\mathrm{D}_{2}$ and $\mathrm{C}_{2}$ is to recycle the energy that is stored in the leakage inductance that presents in the couple-inductor. Therefore, the input ripple current is reduced.

Figure 10 displays the output voltage of the proposed converter. From Figure 11, at time, $t=0 \mathrm{~s}$, the voltage starts to increase, and it reaches the maximum value $\mathrm{Vo}_{(\max )}=308 \mathrm{~V}$ at $t=0.15$. The value of $\mathrm{Vo}$ becomes stable at $\mathrm{t}=0.2 \mathrm{~s}$ which gives the $\mathrm{V}_{\mathrm{o}(\mathrm{rms})}=300 \mathrm{~V}$.

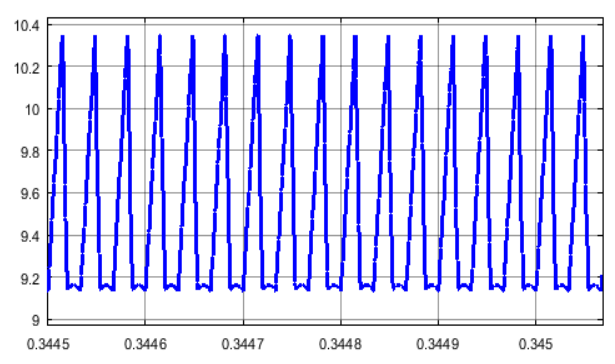

Figure 9. Input current

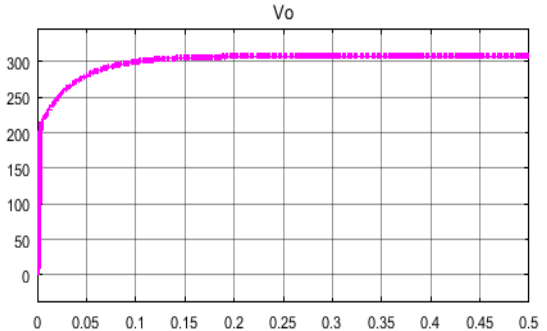

Figure 10. Output voltage

Design and development of SEPIC DC_DC boost converter for photovoltaic... (Ibrahim Alhamrouni) 
Figure 12 displays the output current of the proposed converter. From Figure 11 , at time, $\mathrm{t}=0 \mathrm{~s}$, the current starts to increase, and it reaches the maximum value $I_{o(\max )}=0.7517 \mathrm{~A}$ at $\mathrm{t}=0.15 \mathrm{~s}$. The value of Io

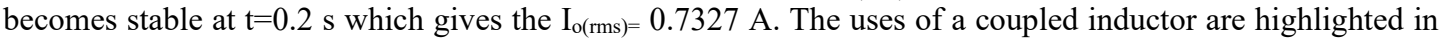
this paper to increase the voltage gain. Coupled inductor is used to lower the component count with improved integration and reduce the requirement of inductance. $C_{3}$ in this converter acts as the voltage multiplier which increases the voltage gain. Hence, the output voltage is increased by $\mathrm{M}$ as mentioned in (11).

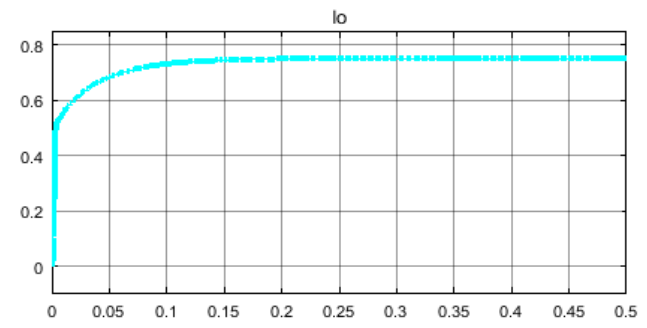

Figure 11. Output current

\subsubsection{Voltage gain}

Voltage gain means how big the output voltage than the input voltage. DC voltage gain which is also called as steady-state voltage gain is the ratio of the output voltage to the input voltage. The proposed converter is operated with voltage gain, $M$. The value of the voltage gain, $M$ can be calculated by using the (11):

$$
\mathrm{M}=\frac{V_{O}}{V_{i}}=11.5
$$

\section{CONCLUSION}

The design of new SEPIC-DC-DC converter is based on topology to regulate the output voltage of the renewable energy sources focusing on PV. Hence, from this study, continuous current and high voltage conversion gain can be achieved. Besides that, this circuit design is also able to reduce stress on the power switch which can further improve the efficiency of the DC-DC converter. The proposed converter has been simulated and tested under differnt conditions by MATLAB_SIMULINK. The converter has been analysed based on different switching frequencies and duty cycle. Thus, the outcome of the proposed converter can be achieved by using $\mathrm{D}=0.45$ and $\mathrm{fs}=30 \mathrm{kHz}$. The proposed converter proved the ability to meet the requirmens demanded by PV sources.

\section{ACKNOWLEDGEMENT}

The authors would like to express their gratitude to Universiti Kuala Lumpur for supporting and funding this research under grant No. str18005.

\section{REFERENCES}

[1] Varesi, K., Hosseini, S. H., Sabahi, M., Babaei, E., and Vosoughi, N., "Performance and design analysis of an improved non-isolated multiple input buck DC-DC converter, " IET Power Electronics, vol. 10(9), pp. 1034-1045, 2017.

[2] Li W, Lv X, Deng Y, Liu J, He X., "A review of non-isolated high step-up DC/DC converters in renewable energy applications," In Applied Power Electronics Conference and Exposition, 2009. APEC 2009. Twenty-Fourth Annual IEEE Feb 15, pp. 364-369, 2009.

[3] Alhamrouni, Ibrahim, Wan Ismail Hanis, Mohamed Salem, Fadi M. Albatsh, and Bazilah Ismail., "Application of DC-DC converter for EV battery charger using PWM technique and hybrid resonant." In Power and Energy (PECon), 2016 IEEE International Conference on, pp. 133-138, 2016.

[4] Zhang, Zhe, Maria C. Mira, and Michael AE Andersen., "Analytical comparison of dual-input isolated dc-dc converter with an ac or dc inductor for renewable energy systems." In Future Energy Electronics Conference and ECCE Asia (IFEEC 2017-ECCE Asia), IEEE 3rd International, pp. 659-664, 2017.

Int J Pow Elec \& Dri Syst, Vol. 10, No. 1, March 2019 : 406 - 413 
[5] Mohod, Sharad W., and Abhijit V. Padgavhankar., "Closed loop digital controller of DC-DC converter for renewable energy source (PV Cell)," In Renewable Energy and Sustainable Energy (ICRESE), 2013 International Conference on IEEE, pp. 112-116, 2013.

[6] Sravanakumar, Rajana, A. Sivaprasad, S. Kumaravel, and S. Ashok., "Development of Dual input—Single output high frequency transformer coupled DC-DC converter for renewable energy integration," In Engineering, Technology and Innovation/International Technology Management Conference (ICE/ITMC), 2015 International Conference on IEEE, pp. 1-5, 2015.

[7] Salem, M., Jusoh, A., Idris, N.R.N., Sutikno, T. and Buswig, Y.M.Y., "Phase-shifted series resonant converter with zero voltage switching turn-on and variable frequency control. " International Journal of Power Electronics and Drive Systems (IJPEDS), 8(3), pp.1184-119, 2017.

[8] Moradpour, Reza, Hossein Ardi, and Abdolreza Tavakoli, "Design and Implementation of a New SEPIC-Based High Step-Up DC/DC Converter for Renewable Energy Applications." IEEE Transactions on Industrial Electronics, vol. 65, no. 2, pp. 1290-1297,2018.

[9] Lamb, Jacob, and Behrooz Mirafzal, "An adaptive SPWM technique for cascaded multilevel converters with timevariant dc sources." IEEE Transactions on Industry Applications, vol. 52, no. 5, pp. 4146-4155, 2016.

[10] Ardi, Hossein, Ali Ajami, and Mehran Sabahi, "A Novel High Step-Up DC-DC Converter With Continuous Input Current Integrating Coupled Inductor for Renewable Energy Applications." IEEE Transactions on Industrial Electronics, vol. 65, no. 2, pp. 1306-1315, 2018.

[11] Salem, Mohamed, Awang Jusoh, N. Rumzi N. Idris, Himadry Shekhar Das, and Ibrahim Alhamrouni, "Resonant power converters with respect to passive storage (LC) elements and control techniques-An overview." Renewable and Sustainable Energy Reviews, vol. 91, pp. 504-520. 2018.

[12] Salem, M., Jusoh, A. and Idris, N.R.N, "Implementing buck converter for battery charger using soft switching techniques". In Power Engineering and Optimization Conference (PEOCO), 2013 IEEE 7th International on IEEE, pp. 188-192. 2013.

[13] Salem, M., Jusoh, A., Idris, N.R.N., Sutikno, T. and Abid, I., "ZVS full bridge series resonant boost converter with series-connected transformer. " International Journal of Power Electronics and Drive Systems (IJPEDS), 8(2), pp.812-825. 2017.

[14] Salem, M., Jusoh, A., Idris, N.R.N. and Alhamrouni, I., "Extension of Zero Voltage Switching range for series resonant converter, " In Energy Conversion Conference (CENCON), 2015 IEEE Conference, pp. 171-175. 2015.

[15] Salem, M., Jusoh, A., Idris, N.R.N. and Alhamrouni, I., "A review of an inductive power transfer system for EV battery charger. " European Journal of Scientific Research, 134, pp.41-56. 2015

[16] Salem, M., Jusoh, A., Idris, N.R.N. and Alhamrouni, I., "Comparison of LCL resonant converter with fixed frequency," and variable frequency controllers. In Energy Conversion (CENCON), IEEE Conference, pp. 84-89 2017. 